\title{
Awakening Giant: International Business in China Growth, Opportunities and Challenges
}

\author{
Ananda Wickramasinghe ${ }^{1} \&$ Alberto Ordigoni ${ }^{1}$ \\ ${ }^{1}$ Sydney Business School, University of Wollongong, Australia \\ Correspondence: Ananda Wickramasinghe, Sydney Business School, University of Wollongong, Wollongong, \\ NSW, Australia. Tel: 61-2-4298-1435. E-mail: ananda@uow.edu.au
}

Received: July 19, 2013

Accepted: September 12, 2013

Online Published: December 23, 2013

doi: 10.5539/ibr.v7n1p109

URL: http://dx.doi.org/10.5539/ibr.v7n1p109

\begin{abstract}
This paper analyses China's growth through a developmental state framework, taking into account the positive role of the state in deliberately fostering a strategic industrial policy, with the aim of creating a process of rapid industrialisation and overcoming structural and technological constraints. It is argued that China growth has been achieved through a strong industrial policy implemented by state intervention in a way similar to other late-industrialised East Asian countries such as Japan, South Korea, Taiwan and Hong Kong. In particular, there are three main features in Chinese development typical of a developmental state policy: the constant control by the state of economic prices and allocation of resources, the focus on export-oriented firms and the openness towards foreign direct investment in order to overcome technology backwardness. China's growth has been analysed from an historical perspective in order to identify the key government reforms which have sustained and enhanced economic growth within the country. It is demonstrated that the industrial policy played a significant role in creating rapid industrialisation.
\end{abstract}

Keywords: international business, FDI, China, developmental state, economic growth, industrial policy

\section{Introduction}

This paper analyses China's development, from the start of its openness policy to the present day. It is argued that China's growth occurred due to the specific developmental policies pursued by the Chinese state in order to bring about rapid industrialisation. In pursuing this strategy, the openness towards FDI in order to acquire capital and technology represents a key feature implemented by Chinese policy makers. Moreover this paper argues that China's development can be studied through a developmental state framework, a theoretical framework used to analyse the growth processes of other Asian economies that have experienced rapid industrialisation. Furthermore, the aim of this paper is to relate previous analysis on specific Chinese economic reforms to this particular theoretical framework, in order to highlight the developmental strategy pursued by Chinese policy makers from 1978 onwards. In the first part of the paper the developmental state literature will be briefly analysed. In the second part, China's developmental policies will be discussed, as well as their impact on China's growth and economic environment.

The developmental state theory represents a useful framework to explain the rapid industrialisation experienced by Asian economies. This theory takes into account the positive role of the state in deliberately fostering a strategic industrial policy with the aim of creating a process of rapid industrialisation and overcoming structural and technological constraints. Johnson (1982) developed this theory in his seminal book "Miti and the Japanese miracle" in order to explain rapid Japanese development in the second half of the last century. Likewise, Amsden (1989) utilised a similar developmental state framework to analyse South Korea's rapid industrialisation. The developmental state framework can be summarised into four main features. Firstly, the state has great autonomy from the civil society along with a strong decision power, and enhances the transfer of foreign technology into the country (Haggard, 1990). Secondly, local companies create indigenous technological capabilities through the assimilation of imported technologies (Enos, 1991). Thirdly, the economic policy pursued by the government aims to maintain low inflation rates, low interest rates, and low exchange rate (Corbo \& Suh, 1992). Lastly, the state focuses on an industrial policy which creates competitive advantage by fostering the right mix of industries without completely and indefinitely sheltering local firms from international competition (Okimoto, 1989). As a result, the growth process is not based on static price-allocation criteria driven by market forces, instead 
development is achieved by the state's deliberate distortion of relative prices and by resources allocation. This strategy is exploited by using subsidies such as financial incentives, or state patronage of specific industries (Amsden, 1989). The allocation of subsidies puts the state in the role of entrepreneur, since their use implies a decision on what, when and how much to produce (Amsden, 1989). As Wade (1990) pointed out, this strategy enables the government to invest in industries considered strategic, as well as to expose these infant industries to international competition. Furthermore, the scope of the government is to create an oligopolistic industry structure in those sectors considered strategic. The purpose of creating a high level of economic concentration is to provide local firms with the necessary market power to survive the hardship of late entry, and to support a high level of investment and the exploitation of large economies of scale (Amsden, 1989). Nonetheless, these oligopolistic industries' rent-seeking behaviors are hindered by a strict state control on credit access as well as by a strong intra-industry competition (D'Costa, 1994). Along with strong physical capital accumulation, the state also provides human capital accumulation, fostering an educated workforce with a strong technological background. However, the state excludes the labor force from any major decision making, in order to have total control over its developmental strategy (Hart-Landsberg, 1993). Furthermore, as Sachs and Williamsons (1985) argued, the state enhances its industrial policy through a trade policy that maintains competitive exchange rates to stimulate exports, along with certain forms of import restrictions to protect local firms. Finally, the crucial role of domestic firms should be considered, in developing indigenous capabilities from the foreign technology acquired through the inflow of FDI within the country.

\section{Method}

In this paper, China's path towards industrialisation has been analysed, from a historical perspective, from the start of its openness policy in 1978 to the present day. This period of time has been divided in three hypothetical phases to identify the major steps that China undertook on the road to industrialisation. The major economic reforms have been analysed as well as their impact on the major economic variables such as TFP, human and physical capital accumulation and FDI flows. Furthermore, the literature on the subject has been utilised to explain China's growth through a developmental state framework.

\section{Results}

The first phase could be dated as starting in 1978, with the economic reforms introduced by Deng Xiaoping. These seminal reforms sought to overcome the disastrous legacy of Mao's "Great leap forward" program, a disastrous state program implemented to control agriculture and achieve rapid industrialisation. This policy not only resulted in thousands of deaths due to famine, but also isolated China from the progress of modern times (Coase \& Wang, 2012). This first initial round of reforms had a critical impact on China's development, in particular these reforms created a process of mutually reinforcing positive feedback efforts and put the country on a path of development (Nolan, 2004). The main result of these reforms was the start of a process of primitive accumulation within the country, where primitive accumulation is defined as the process through which capitalist production can start. However, since at the beginning of the economic reforms China was still a planned economy and all the assets were state owned, the capital formation had to be achieved by converting state-owned land and productive facilities into capital (Webber, 2012). The first reform introduced by Chinese policymakers was the rural reform. This reform had an outstanding importance as its success represented a positive feedback to implement more changes into the planned economy. The purpose of the rural reform was to deal with the major failure of the planned economy, which had been focusing on ambitious and expensive industrial projects while neglecting consumers' simple demands for basic goods and services. As Naughton (2006) argued, this reform was made on two simple policy decisions. Firstly, procurement targets for grain were reduced, procurement prices were raised and prices for agricultural products above the procurement targets were raised (Naughton, 2006). Secondly, collective farmers were allowed to choose their own system of organising and selling the agricultural output. The dramatic price incentives for farmers to produce and sell their products once they had met the required procurement, along with the freedom to organise the collective farms, led to a dramatic change in the structure of collectives. This policy recreated the traditional farm household economy and reduced the collective to a role of landlord, where farm households managed the entire agricultural production cycle on a specific plot of land subjected to a contractual agreement (Naughton, 2006). Due to the implementation of the rural reform, agricultural output started rising, farm households were encouraged to utilise modern imputs such as chemical fertilisers and agricultural machines, and agriculture productivity rose. According to Lyn (1992) the average annual growth rate of the Chinese agricultural sector moved from $2.2 \%$ in the years $1952-1978$ to $7.7 \%$ in the years 1978-1984.

The rural reform also represented a blueprint for the subsequent commercial and industrial reforms that were pursued from 1978 to the mid 1990s. Following the rural reform framework, the Chinese government 
implemented a new policy known as "the dual-track system". This system was characterised by the existence of both planned, and market, coordination systems for the allocation of goods within the state industrial sector (Guthrie, 2006). The key elements of the command economy were maintained, while at the same time state owned industries were given opportunities and incentives to experiment market oriented strategies. However, this system represented only a double coordination mechanism for the allocation of goods and did not imply any form of privatisation since all factories were technically state-owned (Naughton, 2006). The main feature of this system was the opportunity for firms to sell all the goods produced above the production targets at market prices. Therefore, although state owned enterprises were subjected to a compulsory plan of production that covered the majority of their production capacity, they faced market prices on the margin for production above plan (Byrd, 1991). The existence of profitable opportunities beyond the state production plan represented a great incentive for companies to expand their business. Moreover, the Chinese government decided to keep the overall size of the production plan fixed in absolute terms (Naughton, 2006). As a consequence the economy grew outside the plan and the latter became proportionally less and less important, and in the end irrelevant. During this phase, town village enterprises (TVEs) played a key role in transforming the Chinese economy from a planned to a market economy. Between 1978 and the mid 1990s, TVEs led the growth of China and truly represented the most dynamic part of its economy (Naughton, 2006). According to Naughton research (2006), TVE employment increased from 28 million in 1978 to 135 million in 1996, moreover TVE added value in GDP terms, which increased from $6 \%$ in 1978 to $26 \%$ in 1996 . The positive performance of the TVEs was favoured by the support of local government. In particular, TVEs enjoyed very low tax rates, and extremely low tax rates on profits, as well as access to capital and credit support (Naughton, 2006).

Furthermore, international opening reforms were implemented along with the domestic economy reforms. Chinese policy makers adopted a dualistic trade regime that enabled the country to encourage exports while protecting domestic markets. As Naughton (2006) showed, the first step in opening was to allow Hong-Kong firms to sign export contracts with Chinese firms, and set Special Export Zones (SEZs) in Guangdong and Fujian provinces in 1978. In 1986, the Chinese government decided to implement a more aggressive export-strategy and started the "Coastal Development Strategy" in order to attract foreign investors. This policy enabled all types of firms in the coastal provinces to engage in processing and assembling contracts with foreign firms and boosted China's export expansion. As Nolan (2004) argued, the economic environment in the Delta region of China during this first round of export reforms can be linked to a "Lewis model" type (Lewis, 1954). In other words, for Hong Kong capitalists the Delta region represented an economic region with an unlimited supply of unskilled labor at a constant or sometimes declining real wage rate where it was easy to accumulate great amounts of capital (Nolan, 2004). As Fung (1998) showed, by 1993 about four-fifth of Hong Kong manufacturers had moved their production facilities to the Delta region employing three to four million Chinese workers in almost 25,000 factories. However, during this initial phase the impact of FDI on China's economy and total export was relatively low. Zhang and Song (2001) showed that in 1985, five years after the creation of SPEs, the export generated by foreign-invested enterprises counted for only $1 \%$ of China's total export.

The second phase could be dated as starting in 1992 and represented the turning point for China. During the years from 1992 to 2001, the Chinese economy faced a deep restructuring which removed the last remaining institutions of the old planned economy. Although several reforms had been implemented since 1978, in the mid 1990s the economy was still dominated by state-owned enterprises (SOEs). As Naughton (2006) pointed out, in 1996 the Chinese economy had a tripod structure in which state, collective and private firms each counted for one third of the total output. Nonetheless the SOEs, and in particular the lack of true private ownerships rights, represented a hinderance on economic development. Furthermore, SOEs were afflicted by endemic problems such as contractors' opportunistic behaviour, under-utilised employees and high asset-liability ratios which made most of these enterprises unprofitable and dependent on state-subsidies (Chen, Jefferson, \& Zhang, 2011). As a result, Chinese policymakers implemented a series of reforms that both created an institutional framework in which private companies could operate, and restructured most of the old SOEs. A true milestone was represented by the "company law" that guaranteed legal and autonomous entities for private, collective and state enterprises, and separated enterprises, legally and operationally, from the command economy (Guthrie, 2006). This law was particularly important for two reasons. Firstly, it created a legal framework in which the different form of ownerships, state, collective and private, could operate under common rules and secondly it provided a legal way to convert traditional SOEs into private enterprises (Naughton, 2006). This policy was followed by the "grasping the large, and letting the small go" strategy adopted at the $15^{\text {th }}$ Communist Party Congress. Through this policy, Chinese policy makers focused their efforts on key industries which were considered strategic, while giving local governments authority to restructure, privatise or close their firms. As a result, local governments sought to privatise firms considered competitive, as well as to close unproductive and loss making enterprises. As 
Naughton (2006) argued, budget constraints for enterprises were tightened, banks had less access to state funds and started applying higher lending standards and repayment provisions. These reforms led to a huge restructuring of the industrial composition within China, most of the loss-making state-owned firms were closed and the smaller and weaker local firms that could not deal the increased market competition faced bankruptcy. Naughton (2006) demonstrated that "the total number of industrial SOEs dropped from 120,000 in the mid 1990s to only 31,750 in 2004, including all state-controlled corporations" (p. 313). These reforms clearly contributed to boosting growth and productivity within the economy. Chen et al. (2011) calculated that during the reform period the aggregate growth rate of industrial value added was $12.5 \%$ while the growth rate of productivity was $6.7 \%$. Furthermore, Dekle and Vandenbroucke (2012) calculated that the total factor productivity growth per annum for the period $1978-2003$ was $3.7 \%$ in the agricultural sector, $3.2 \%$ in the non-agricultural sector, and in particular the TFP growth for the private sector alone was $8.8 \%$.

The second main element of this period was the huge flow of FDI into the country. As Zhang and Song (2001) showed, in 1985, five years since of the setting of SPEs zones, the total FDI in China amounted to 1661 million dollars. However, after 1992 FDI flows showed an increasing trend throughout the decade, in 1992 FDI flows amounted to 11,007 million dollars and reached 40,390 million at the end of 1999. In addition, the exports generated by foreign-invested enterprices followed a similar positive trend: FIEs share of total exports went from $12.5 \%$ in 1990 to $45.50 \%$ in 1999 (Zhang \& Song, 2001). This flow of FDI can be divided in two macro categories: horizontal FDI involving the transfer of production from abroad, to service the Chinese market, and vertical FDI that sought to take advantage of low-cost production and low wages for the exportation of manufactured goods abroad (Xin \& Whalley, 2010). As Guthrie (2006) argued, the government openness policy attracted massive amounts of FDI into the country which represented a large supply of capital and an efficient means of importing technology and managerial practices. In other words, there was a correlation between FDI openness and TFP growth. As Xu, Lai, and Peng (2008) showed from their study of TFP in 29 of China's provinces during the period from 1994 to 2006, the more open the region was to FDI the faster the companies acquired foreign technology, improved efficiency through learning by doing, and enhanced the level of average human capital accumulation. Moreover, Xu et al. (2008) showed that in the most technological developed regions of China, TFP was increased by three factors: human capital, trade openness and FDI. The impact of the different reform phases on human capital accumulation has been reflected by the human capital growth rates, $\mathrm{Li}$, Liang, Fraumeni, Liu and Wang (2013) calculated that the annual average growth rate of real human capital was 5.74\% between 1985 and 1994 and increased to 7.67\% between 1995 and 2008. In addition, FDI inflows were stimulated by the exchange rate policy pursued by the Chinese government. As Xing showed (2006), the Yuan has faced a devaluation trend since 1994. The devaluation stimulated the export-oriented industry, since the devaluation reduced the cost of labour and other productive inputs relative to foreign markets, attracting FDI (Xing, 2006).

The third phase could be dated to 2001, the year in which China entered the World Trade Organization (WTO). This phase was characterised by a radical change in the Chinese export structure. As Tong and Wong (2012) demonstrated, China's exports shifted from labor-intensive manufacturing in the early 1990s to capital and high technology manufacturing in the late 2000s. The change in the focus of the manufacturing process was a consequence of the development path undertaken by China. China's economy moved from a developing stage where its comparative advantages (cheap labor and an unlimited supply of workers), attracted multinational investors outsourcing their production, to a mature stage where industries were more technology and knowledge based and productions were capital-intensive. As a result, China's factors endowment has become more similar to those in the developed economies. As Yang and Zang (2011) showed, China has reached the 'Lewis turning point'. In other words, China does not possess an unlimited supply of labor anymore, wages are about to increase rapidly in the coming years, leading to higher domestic consumption rates. Finally, in the last few years China has been implementing new reforms. According to the OECD (2010), central authorities have introduced pro-competition measures and competition policy frameworks, restructured the relationship between the government and State Owned Enterprises (SOEs), introduced new labour laws and restructured its financial system. With the implementation of these new rounds of reforms and the continuous positive growth trend, China's economy is now predicted by the OECD (2010) to become as large as the U.S.A.'s by 2016.

\section{Discussion}

The transition of China from a command economy to a market system has been constantly driven and supported by the state. As Naughton (2006) demonstrated, Chinese policy makers gradually opened the economic system to new capitalist elements and favored entrepreneurial behaviours because they considered that these things contributed to developmental objectives. 
According to Guthrie (2006) "the state has consistently and methodically guided the reform process, maintaining control over the majority of the industrial economy and tightening fiscal constraints for the inefficient state sector at only a gradual rate" (p. 13), furthermore "the state has experimented with, and gradually introduced, the policies and laws through which new markets that increasingly govern economic processes in China have been constructed" (p. 13). In other words, Chinese policy makers have been able to create an endogenous process of growth stimulating a rapid accumulation of capital and technology advancement that boosted productivity gains. In pursuing this strategy, the export-oriented economy, created with the coastal development strategy and the openness towards FDI, played a major role in overcoming the main constraints on China's development: a scarce supply of capital and technology backwardness. As Guthrie (2006) showed, China's growth was based on three pillars: firstly, the gradual retirement of the state control over the economy without rapid privatisations, secondly, the constant growth of FDI, and thirdly, the gradual construction of a legal and institutional environment that could support economic changes. Furthermore, China's development shows some key features of a developmental state framework. Firstly, the state has always had a strong and independent decision making power, even after 1978. Fairbank and Goldman (2006) argued that the communist party is no more than the inheritor of the one of the world's longest tradition of autocracy. In other words, as Robins argued (2010), China has never experienced a plurastic institutional system where the civil society was allowed to participate in and control government's decisions. As a result, although the party-state has implemented wide economic reforms towards a market-oriented economy, it never allowed civil society to take part in the decision making process. As a result, economic policies have been imposed by Chinese policy makers through bottom-down logic in order to achieve their specific developmental objectives. This independent decision power has been expressed through a strict control on labour force, capital flows, control on FDI flows and by controlling strategic industries. Secondly, FDI played a major role in China's development and represented a mean to acquire foreign technology, managerial skills, know-how and capital (Guthrie, 2006). In order to attract FDI, Chinese policy makers created a favourable export oriented environment by creating special export zones, keeping the Yuan undervalued, ensuring a stable macroeconomic environment and creating the legal and institutional framework for a market economy. These policies strengthened China's comparative advantage, a relatively cheap cost of labour, and made the country even more attractive for foreign investors. All together, these policies boosted a growth process within the country and set China on a path of development.

However, China's move towards development has created both opportunities and challenges for the country. One of the key issues that will require solving is the striking inequality among the Chinese population. The rapid industrialisation process in China has undoubtedly created growth and wealth but it has been achieved by deliberately favouring business interests. As Amsden (1989) demonstrated, within a developmental state framework the state supports businesses in order to create a sustained growth process while at the same time it strictly disciplines it in order to impede business interests from overlapping with those of the society at large. Nonetheless, this support implies an unequal redistribution of the wealth to a specific segment of the society, the owners of capital, which in turn creates inequalities. According to the OECD (2013), inequality reached a peak in 2008 and is now declining. Nevertheless, Chinese policy makers will have to deal with inequality and provide a better redistribution of wealth, especially in the rural areas where the average income is far lower than the income in the urban areas. Another key issue is the reform process and its future directions. Although China has set its reformation path in the right direction, many changes are still required. The central government has not completely liberalised the economy, and competition in sectors considered strategic by the party has not been permitted, SOEs continue to operate along with private enterprises. The inflow of capital in China's capital market is restricted to specific quotas and the financial sector is still heavily controlled. These issues mean that new market reforms need to be implemented in the next decade in order to fully develop a stable market environment. Lastly, China's growth opens a discussion on the democratisation process within the country. With income and living standard rising, the demand for democracy within the country is increasing and some authors such as Guthrie (2006) argue that democracy in China is inevitable due to the process of development that is changing the country. However, China is still a non democratic country and the Chinese political system is heavily controlled by the communist party. This issue could represent one of the hardest challenges for the China in the near future. How will Chinese policy makers cope with the demand for democracy and how will they introduce democratic rules in a country which has been controlled for more than 50 years by a dictatorial government?

\section{Conclusion}

Strong evidence has been presented that China's growth was created and sustained by a specific developmental strategy pursed by the Chinese government. Rather than rely on market forces, Chinese policy makers 
deliberately distorted prices and resources to transform a command economy into a market economy. This process was achieved through a gradual but constant erosion of the planned system along with the construction of a capitalist environment. In implementing this strategy, Chinese policy makers built an export-focused economy and promoted openness towards FDI in order to achieve foreign technologies and capitals. This development strategy shows strong similarities with the developmental policies implemented by other Asian economies such as Japan, Taiwan, South Korea, Singapore and Honk Kong, in order to achieve rapid industrialisation. As a result, China's growth can be analysed through the lens of a developmental state framework. However, the aim of this paper is to encourage future analysis of China's growth through a developmental framework, since the lack of a thorough quantitative analysis of the different policies, in terms of the principal economic variables, poses serious limits to the depth of the study in this article.

\section{References}

Amsden, A. H. (1989). Asia's next giant: South Korea and late industrialization. New York: Oxford University Press.

Byrd, W. A. (1991). The market mechanism and economic reforms in China. Armonk, N.Y: M.E. Sharpe.

Chen, S., Jefferson, G. H., \& Zhang, J. (2011). Structural change, productivity growth and industrial transformation in China. China Economic Review, 22(1), 133-150. http://dx.doi.org/10.1016/j.chieco.2010.10.003

Coase, R. H., \& Wang, N. (2012). How China became capitalist. Basingstoke: Palgrave Macmillan.

Corbo, S., \& Suh, S. M. (1992). Structural adjustment in a newly industrialized country: the Korean experience. Baltimore, MD: The Johns Hopkins University Press.

Dekle, R., \& Vandenbroucke, G. (2012). A quantitative analysis of China's structural transformation. Journal of Economic Dynamics \& Control, 36(1), 119-135. http://dx.doi.org/10.1016/j.jedc.2011.07.004

D'Costa, A. P. (1994). State, steel and strength: Structural competitiveness and development in South Korea. The Journal of Development Studies, 31(1), 44-81. http://dx.doi.org/10.1080/00220389408422348

Enos, J. L. (1991). The creation of technological capability in developing countries. New York: Pinter Publishers.

Fairbank, J. K., \& Goldman, M. (2006). China: A new history. Cambridge, Mass: Belknap Press of Harvard University Press.

Fung, K. C. (1998). Accounting for Chinese trade: some national and regional considerations. In R. E. Baldwin, R. E. Lipsey, \& J. D. Richardson (Eds.), Geography and ownership as bases for economic accounting (pp. 173-204). Chicago: The University of Chicago Press.

Guthrie, D. (2006). China and globalization: The social, economic and political transformation of Chinese society. New York: Routledge.

Haggard, S. (1990). Pathways from the periphery: The politics of growth in the newly industrializing countries. Ithaca, NY: Cornell University Press.

Hart-Landsberg, M. (1993). The rush to development: economic change and political struggle in South Korea. New York: Monthly Review Press.

Johnson, C. (1982). MITI and the Japanese miracle: The growth of industrial policy, 1925-1975. Stanford, California: Stanford University Press.

Lewis, W. A. (1954). Economic development with unlimited supplies of labour. Manchester School of Economic and Social Studies, 22(2), 139. http://dx.doi.org/10.1111/j.1467-9957.1954.tb00021.x

Li, H., Liang, Y., Fraumeni, B. M., Liu, Z., \& Wang, X. (2013). Human capital in China, 1985-2008. Review of Income and Wealth, 59(2), 212-234. http://dx.doi.org/10.1111/j.1475-4991.2012.00517.x

Lin, J. Y. (1992). Rural reforms and agricultural growth in China. The American Economic Review, 82(1), 34-51.

Nolan, P. (2004). China at the crossroads. Cambridge, UK: Polity.

Okimoto, D. I. (1989). Between MITI and the market: Japanese industrial policy for high technology. Stanford, Calif: Stanford University Press.

Organisation for Economic Co-Operation and Development, \& Organisation for Economic Co-operation and Development Staff. (2010). Oecd economic surveys: China 2010. Washington: Organization for Economic 
Cooperation \& Development.

Organisation for Economic Co-Operation and Development, \& Organisation for Economic Co-operation and Development Staff. (2013). Oecd economic surveys: China 2013. Washington: Organization for Economic Cooperation \& Development.

Robins, F. (2010). China: A new kind of "mixed" economy? Asian Business \& Management, 9(1), 23-46. http://dx.doi.org/10.1057/abm.2009.21

Sachs, J. D., \& Williamson, J. (1985). External debt and macroeconomic performance in Latin America and East Asia. Brookings Papers on Economic Activity, 1985(2), 523-573. http://dx.doi.org/10.2307/2534445

Tong, S. Y., \& Wong, J. (2012). China's Economy. In Gamer, R. E. (Ed.), Understanding contemporary China. Boulder, Colo: Lynne Rienner Publishers.

Wade, R. (1990). Governing the market: Economic theory and the role of government in East Asian industrialization. Princeton, NJ: Princeton University Press.

Webber, M. J. (2012). Making capitalism in rural China. Cheltenham, UK: Edward Elgar. http://dx.doi.org/10.4337/9780857934109

Xin, X., \& Whalley, J. (2010). China's FDI and non-FDI economies and the sustainability of future high Chinese growth. China Economic Review, 21(1), 123-135. http://dx.doi.org/10.1016/j.chieco.2009.11.004

Xing, Y. (2006). Why is China so attractive for FDI? The role of exchange rates. China Economic Review, 17(2), 198-209. http://dx.doi.org/10.1016/j.chieco.2005.10.001

Xu, H., Lai, M., \& Peng, Q. (2008). Openness, human capital and total factor productivity: Evidence from China. Journal of Chinese Economic and Business Studies, 6(3), 279-289 http://dx.doi.org/10.1080/14765280802283576

Yang, J., \& Zhang, X. (2011). China has reached the Lewis turning point. China Economic Review, 22(4), 542-554. http://dx.doi.org/10.1016/j.chieco.2011.07.002

Zhang, K. H., \& Song, S. (2001). Promoting exports: The role of inward FDI in China. China Economic Review, 11(4), 385-396. http://dx.doi.org/10.1016/S1043-951X(01)00033-5

\section{Copyrights}

Copyright for this article is retained by the author(s), with first publication rights granted to the journal.

This is an open-access article distributed under the terms and conditions of the Creative Commons Attribution license (http://creativecommons.org/licenses/by/3.0/). 